\title{
Local pH elevation mediated by the intrabacterial urease of Helicobacter pylori cocultured with gastric cells
}

\author{
Christoph Athmann, ${ }^{1}$ Ningxin Zeng, ${ }^{1}$ Tao Kang, ${ }^{1}$ Elizabeth A. Marcus, ${ }^{1}$ \\ David R. Scott, ${ }^{1}$ Marina Rektorschek, ${ }^{2}$ Anita Buhmann, ${ }^{2}$ Klaus Melchers, ${ }^{2}$ \\ and George Sachs ${ }^{1}$
}

\author{
${ }^{1}$ University of California at Los Angeles and Veterans Administration, Greater Los Angeles Healthcare System, \\ Los Angeles, California, USA \\ ${ }^{2}$ Byk Gulden, Konstanz, Germany \\ Address correspondence to: George Sachs, Wadsworth Veterans Administration Hospital, Building 113, \\ Room 324, 11301 Wilshire Boulevard, Los Angeles, California 90073, USA. \\ Phone: (310) 268-3923; Fax: (310) 312-9478; E-mail: gsachs@ucla.edu. \\ Christoph Athmann and Ningxin Zeng contributed equally to this work.
}

This paper is dedicated to the memory of John Walsh, friend, tennis partner, and colleague.

Received for publication January 11, 2000, and accepted in revised form June 28, 2000.

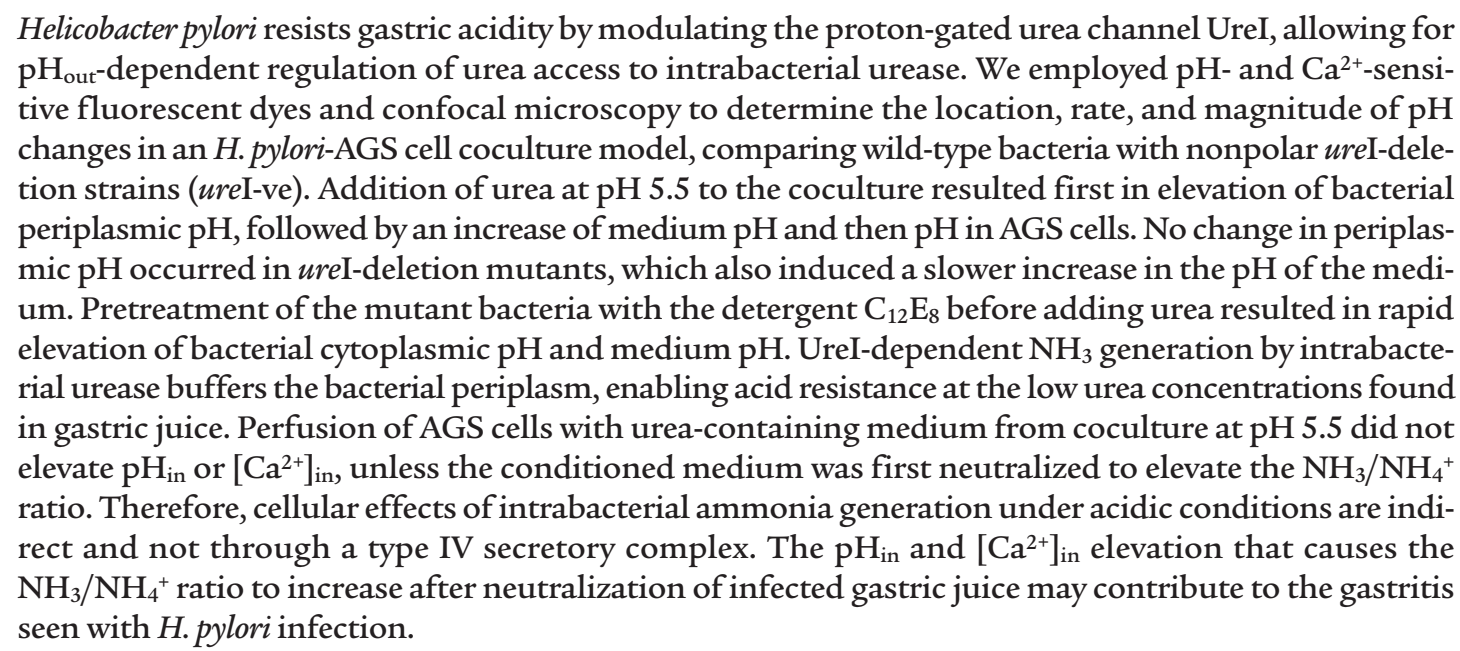

J. Clin. Invest. 106:339-347 (2000).

\section{Introduction}

The neutralophile Helicobacter pylori is a pathogen that resists gastric acidity and colonizes the human stomach (1). No other organism appears to have both capabilities. Urease negative mutants are unable to colonize a variety of animal models (2-4), implicating the large quantities of urease made constitutively by $\mathrm{H}$. pylori in acid resistance of the organism. There are seven genes in the urease gene cluster (5). ure $\mathrm{A}$ and $u r e \mathrm{~B}$ encode the structural subunits of urease, and $u r e \mathrm{E}, \mathrm{F}, \mathrm{G}$, and $\mathrm{H}$ encode accessory proteins necessary for assembly and $\mathrm{Ni}^{2+}$ insertion to form active urease (6). Knockout of any one of these four accessory genes prevents or retards synthesis of active urease.

The urease produced by $H$. pylori has a neutral $\mathrm{pH}$ optimum and is irreversibly inactivated at $\mathrm{pH}$ lower than $4.5(7,8)$. The majority of this urease is intrabacterial, with a minor quantity adhering to the surface after 24-48 hours of culture (9). The $\mathrm{pH}$ profile of urease in intact bacteria, in contrast to that of free or sur- face urease, shows that there is little activity at neutral $\mathrm{pH}$. However, with increasing acidity, urease activity increases between 10- and 20-fold as the $\mathrm{pH}$ falls from 6.0 to 5.0 , and thereafter remains steady down to $\mathrm{pH}$ $2.5(10,11)$. These properties of the surface and intrabacterial urease argue for a greater role of intrabacterial than of surface urease in gastric acid resistance (11).

Acid activation of intrabacterial urease is due to expression of the third gene in the urease gene cluster, ureI, that encodes a $\mathrm{H}^{+}$gated urea channel, allowing an increase of urea permeability of the bacterial membrane by at least 300 -fold as medium $\mathrm{pH}$ becomes acidic (12). The presence of this acid-activated urea channel in the inner membrane of the organism is necessary for efficient utilization of the urea present in gastric juice. These data explain the requirement for both urease and UreI for survival at a medium $\mathrm{pH}$ of less than 4.0 and for infection of animal models $(13,14)$.

H. pylori maintains a constant inner membrane potential of $-101 \mathrm{mV}$ in the presence of $1-5 \mathrm{mM}$ urea in 
strong buffer between $\mathrm{pH} 3.0$ and 5.0 (11). At this potential, assuming a constant proton motive force of approximately $-220 \mathrm{mV}$ and an internal $\mathrm{pH}$ of approximately 8.0, the $\mathrm{pH}$ of the periplasm is maintained at a $\mathrm{pH}$ of approximately 6.0 by internal urease activity (7). This is within the range of the optimal $\mathrm{pH}$ for growth of the organism in vitro in the absence of urea (15). $\mathrm{NH}_{3}$ efflux across the bilayer, and perhaps also through UreI, is predicted to elevate the periplasm to a $\mathrm{pH}$ of approximately 6.0 to account for the elevation of membrane potential (7). Buffering of the periplasm needs much less urease activity than does buffering of the external medium immediately surrounding the organism.

All infective $H$. pylori strains have high levels of urease and most likely UreI, as do other gastric Helicobacter species, such as Helicobacter felis, mustelae, or nemestrinae (11). All patients have gastritis, although only $20 \%$ develop symptoms and disease. All infecting organisms, although varying widely in their expression of genes in the pathogenicity island, will generate large quantities of $\mathrm{NH}_{3}$ that converts to $\mathrm{NH}_{4}{ }^{+}$in gastric acid. Alkalinization of the cytoplasm of many eukaryotic cells results in elevation of intracellular calcium (16) and release of cytokines such as IL-1 $\beta$ (17). H. pylori infection increases cytokine production in stomach and infected cocultures $(18,19)$. High concentrations of $\mathrm{NH}_{3}$ in the cytoplasm of the organisms could directly alkalinize the cytoplasm of cells to which $H$. pylori adhere by direct entry from the organism into the cells via the type IV secretory system possessed by the organism (20-24). If $\mathrm{NH}_{3}$ has to leave the organism under the acidic conditions at which it is produced before entry into cells to which it adheres, it is present mainly as impermeant $\mathrm{NH}_{4}{ }^{+}$in the gastric juice. However, upon entry into the duodenum or at the base of antral glands that absorb, rather than secrete, $\mathrm{H}^{+}$, or during periods of gastric neutrality as occur during the digestive phase, the impermeant $\mathrm{NH}_{4}{ }^{+}$converts to the permeant $\mathrm{NH}_{3}$. This molecule is able to rapidly enter gastric epithelial cells and the $\mathrm{G}$ cell or $\mathrm{D}$ cell of pyloric glands with consequent intracellular alkalinization. These latter cells respond to elevation of $\mathrm{pH}_{\text {out }}$ by increased release of gastrin ( $G$ cell) or inhibition of somatostatin release (D cell) $(25,26)$, effects that would result in increased acid secretion in response to a meal. As a group, duodenal ulcer patients with antral gastritis have a higher rate of acid secretion than do uninfected subjects, thought to be due to the increased gastrin or decreased somatostatin release resulting from $H$. pylori infection $(27,28)$.

The work reported here used a coculture system with gastric-derived AGS cells and H. pylori. In this coculture, the organisms adhere to the AGS cells (29). Both confocal and video microscopy were used to define the site(s) at which intrabacterial urease has a buffering action. Microscopy also allowed visualization of the route of $\mathrm{NH}_{3}$ access to the AGS cells contacted by the bacteria. The data show that acidic $\mathrm{pH}_{\text {out }}$ activation of intrabacterial urease elevates periplasmic and then medium $\mathrm{pH}$. This does not happen or is much slower in the absence of
UreI, and all medium $\mathrm{pH}$ changes are completely inhibited by $10 \mu \mathrm{M}$ flurofamide, a urease suicide inhibitor. The generation of $\mathrm{NH}_{3}$ at $\mathrm{pH} 5.5$ had no effect on the intracellular pH of AGS cells to which the bacteria adhered until medium $\mathrm{pH}$ increased. In separate experiments, when AGS cells were perfused with medium that had been conditioned by perfusion of the coculture with urea at pH 5.5 (but not at 7.4) and then was titrated to $\mathrm{pH}$ 7.4, sufficient $\mathrm{NH}_{3}$ was then present to alkalinize AGS cells, which resulted in an elevation of $\left[\mathrm{Ca}^{2+}\right]_{\text {in }}$.

\section{Methods}

Culture of H. pylori. The H. pylori strain ATCC 43504 and an ATCC 43504 ureI negative mutant were used in this study. ATCC 43504 was grown on blood agar plates (BBL TSA 5\% sheep blood; Becton Dickinson Microbiology Systems, Cockeysville, Maryland, USA) in a microaerophilic atmosphere $\left(5 \% 0_{2}, 10 \% \mathrm{CO}_{2}, 85 \% \mathrm{~N}_{2}\right)$ at $37^{\circ} \mathrm{C}$ for 24 hours. The ureI- mutant was grown on BHI plates in this atmosphere (Difco Laboratories, Detroit, Michigan, USA) supplemented with $5 \%$ FCS and $0.25 \%$ yeast extract containing $1 \%$ kanamycin. Cells from one plate were harvested into $1 \mathrm{~mL}$ of the growth medium used for AGS coculture, and the OD at $600 \mathrm{~nm}$ was measured. Aliquots were taken for the different experiments.

Culture of AGS cells. AGS cells were cultured on round cover slips (No. 1; Fisher Scientific Co., Pittsburgh, Pennsylvania, USA) in a six-well plate to confluence. DMEM/F12 (GIBCO BRL, Rockville, Maryland, USA) was used as the culture medium, containing $10 \mathrm{mg} / \mathrm{mL}$ $1 \%$ gentamycin (GIBCO BRL), 1\% L-glutamine-penicillin-streptomycin solution (Sigma Chemical Co., St. Louis, Missouri, USA), and 10\% FCS.

Coculture of AGS cells and bacteria. AGS cells were washed with the growth media lacking antibiotics. Cover slips were transferred into a new six-well plate with each well containing $2 \mathrm{~mL}$ of the same medium. H. pylori was added at an $\mathrm{OD}_{600}$ of 0.4 and cocultured for 1 hour in $95 \% \mathrm{O}_{2}$ and $5 \% \mathrm{CO}_{2}$. The cover slip was removed and mounted in an Attofluor chamber (Molecular Probes Inc., Eugene, Oregon, USA) and washed twice with Hp-medium (see later here). The chamber was placed in a heated stage (Medical Systems Inc., Greenvale, New York, USA) at $37^{\circ} \mathrm{C}$ and attached to a peristaltic pump for superfusion. Chamber fluid was exchanged at a rate of three times per minute during perfusion. The chambers were viewed either in a Zeiss LSM410 or 510 confocal microscope or imaged in a Zeiss Axiovert TV100 microscope (Carl Zeiss Inc., Thornwood, New York, USA).

Generation of ureI-negative mutants. Mutants were made according to a published procedure that is only presented in outline here (30). Standard procedures (31) were used for isolation and treatment of plasmid DNA. Escherichia coli DH5 $\alpha$ was transformed by electroporation (Gene Pulser II; Bio-Rad Laboratories Inc., Hercules, California, USA). Transformation was carried out according to a standard operation protocol using a 2.5 $\mathrm{kV}$ pulse. The electroporated bacteria were plated onto 
LB plates (LB agar base; GIBCO BRL) supplemented with $50 \mathrm{mg} / \mathrm{mL}$ ampicillin. The DNA was generated by PCR of selected primers as detailed previously (30).

For full-length deletion of the ure gene in the chromosome of H. pylori, a plasmid ( $p U C u r e B k a n R u r e E$ ) was designed, carrying a kanR open reading frame with upstream (ureB) and downstream (ureE) sequences from ureI to allow nonpolar replacement of this gene. The template used for PCR amplification of the ure $\mathrm{B} / \mathrm{E}$ sequences was plasmid pHP808, provided by H. Mobley (Department of Microbiology and Immunology, University of Maryland School of Medicine, Baltimore, Maryland, USA). The DNA template for synthesis of the open reading frame of the kanamycin resistance gene $(k a n R)$ was pUC4K (Amersham Pharmacia Biotech, Piscataway, New Jersey, USA). Synthetic DNA oligonucleotides carrying a Shine Dalgarno sequence were used for PCR amplification of the $5^{\prime}$ regions of ureE as well as the $3^{\prime}$ regions of ureB. The resulting plasmid containing the hybrid DNA fragment, (ureB)kanR(ureE), was transformed into E. coli DH5 $\alpha$. Transformants were screened by growth in LB medium (LB broth base; GIBCO BRL) supplemented with $50 \mathrm{mg} / \mathrm{mL}$ ampicillin. The presence and orientation of the DNA inserts in the vector plasmids were confirmed by restriction analysis.

Growth and selection of ureI-deletion mutants of H. pylori. H. pylori was grown on BHI agar plates (Difco Laboratories) supplemented with $10 \%$ horse serum (GIBCO BRL) in GasPak System (Becton Dickinson Microbiology Systems) jars under microaerophilic conditions for 24 hours. Cells from one plate were harvested in $1 \mathrm{~mL}$ BHI broth (Difco Laboratories) supplemented with 6\% FCS (Eurobio, Toulouse, France). After determination of the OD at $578 \mathrm{~nm}$, the cells were diluted to a final $\mathrm{OD}$ of 0.1 . One milliliter of this suspension was incubated for 4-5 hours at $37^{\circ} \mathrm{C}$ in 24 -well plates in an incubator also in microaerophilic conditions. After addition of $1 \mathrm{mg}$ DNA, the cell suspension was incubated for another 24 hours. The cultures were spread onto BHI agar plates containing $8 \mathrm{mg} / \mathrm{mL}$ kanamycin and $10 \%$ horse serum for selection and growth. The absence of ureI or its expression in the H. pylori mutant was confirmed by PCR and Western blot analysis using antibodies specific for two of the extracytoplasmic loops of the gene product $(11,12)$. The nonpolar nature of the mutants was confirmed by showing normal urease activity in the lysates or after permeabilization with $0.01 \% \mathrm{C}_{12} \mathrm{E}_{8}$ and by complementation using a ureI containing plasmid as detailed elsewhere (32).

Media used for confocal microscopy and $\mathrm{pH}$-metry. In the experiments reported, a $1 \mathrm{mM}$ sodium phosphate buffer at the required $\mathrm{pH}$ values of 5.5 and 7.4 was used containing the following: $138 \mathrm{mM} \mathrm{NaCl}, 5 \mathrm{mM} \mathrm{KCl}$, $1.3 \mathrm{mM} \mathrm{CaCl}_{2}, 0.5 \mathrm{mM} \mathrm{MgSO}_{4}, 10.0 \mathrm{mM}$ glucose, and $1.0 \mathrm{mM}$ glutamine. This buffer medium is referred to as $\mathrm{Hp}$ medium throughout the text.

pH electrode measurements of $\mathrm{pH}$ changes in H. pylori cocultured with AGS cells. A special $\mathrm{pH}$-sensor for microsamples (PHR-146; Lazar Research Laboratory, Los Ange- les, California, USA) was connected to a $\mathrm{pH}$-meter (PHM62; Radiometer Analytical SA, Lyon, France). pH measurement of the chamber medium and simultaneous monitoring of bis-carboxyethylcarboxy-fluorescein-free (BCECF-free) acid fluorescence using confocal microscopy was performed. After $5 \mathrm{mM}$ urea was added to the chamber by perfusion and perfusion stopped, the $\mathrm{pH}$ was monitored every 10 seconds for the first minute, every 30 seconds up to 5 minutes, then every minute up to 10 minutes, and finally every 5 minutes up to 30 minutes. In some experiments, the bacteria were preincubated for 2 minutes with $1 \mu \mathrm{M}$ flurofamide to inhibit external urease while sparing internal urease activity. A total of $10 \mu \mathrm{M}$ flurofamide was used to inhibit all urease activity. In all experimental situations, the presence of $10 \mu \mathrm{M}$ flurofamide abolished $\mathrm{pH}$ changes with the addition of urea.

Confocal microscopy. Confocal experiments were done on a Zeiss LSM 410 or 510 microscope (Carl Zeiss Inc.) using a $63 \times$ or $100 \times$ objective. Higher magnifications were obtained by using the electronic zoom feature provided by the software of the LSM 410/510 as seen in Figure $2 b$ with an electronic zoom factor of $3 \times$ (Carl Zeiss Inc.).

Visualizing the bacteria in coculture. To localize $H$. pylori on the monolayer, AGS cells were stained with the membrane potential dye dithiocarbocyanine $\left[\operatorname{DiSC}_{3}(5)\right]$, which was used to define the AGS cell mitochondria and visualized at $546 \mathrm{~nm}$ excitation and greater than $650 \mathrm{~nm}$ emission. With this dye, the cytoplasm of the AGS cells remains dark. Then BCECF was added to the culture medium and urea added to allow the bacteria to fluoresce. The ATCC 43504 and 43503 strains can be used interchangeably.

Visualizing changes of periplasmic or medium $\mathrm{pH}$ in coculture. BCECF in its free acid form was used at a final concentration of $5 \mu \mathrm{M}$ in Hp medium. The dye was excited at $488 \mathrm{~nm}$ and detected at $515-545 \mathrm{~nm}$. At the start of the experiment, the medium in the coculture chamber was exchanged by superfusion with the Hpmedium containing $5 \mathrm{mM}$ urea at a given $\mathrm{pH}$ and then the perfusion was stopped. For the first 2 minutes, images were collected every 0.78 seconds with a scan rate of 0.78 seconds, and then every 30 seconds at the same scan rate up to 30 minutes. In some experiments, the nonionic detergent $\mathrm{C}_{12} \mathrm{E}_{8}$ was added to the medium at a concentration of $0.01 \%$ to permeabilize the bacterial inner membrane. This concentration of detergent does not disturb bacterial morphology (12). The combination of $\mathrm{pH}$-metry and BCECF fluorescence achieves the goal of defining $\mathrm{pH}$ and the site of $\mathrm{pH}$ elevation.

Visualizing changes in $\mathrm{pH}$ of AGS cells in coculture. Seminaphtharhodfluor-acetomethoxy ester (SNARF-AM) at $10 \mu \mathrm{M}$ was used to load the AGS cells at $37^{\circ} \mathrm{C}$ for 30 minutes and monitor intracellular $\mathrm{pH}$ changes as a function of urea addition at $\mathrm{pH}$ 5.5. Simultaneous monitoring of bacterial periplasmic $\mathrm{pH}$ and medium $\mathrm{pH}$ was carried out using BCECF-free acid fluorescence. 


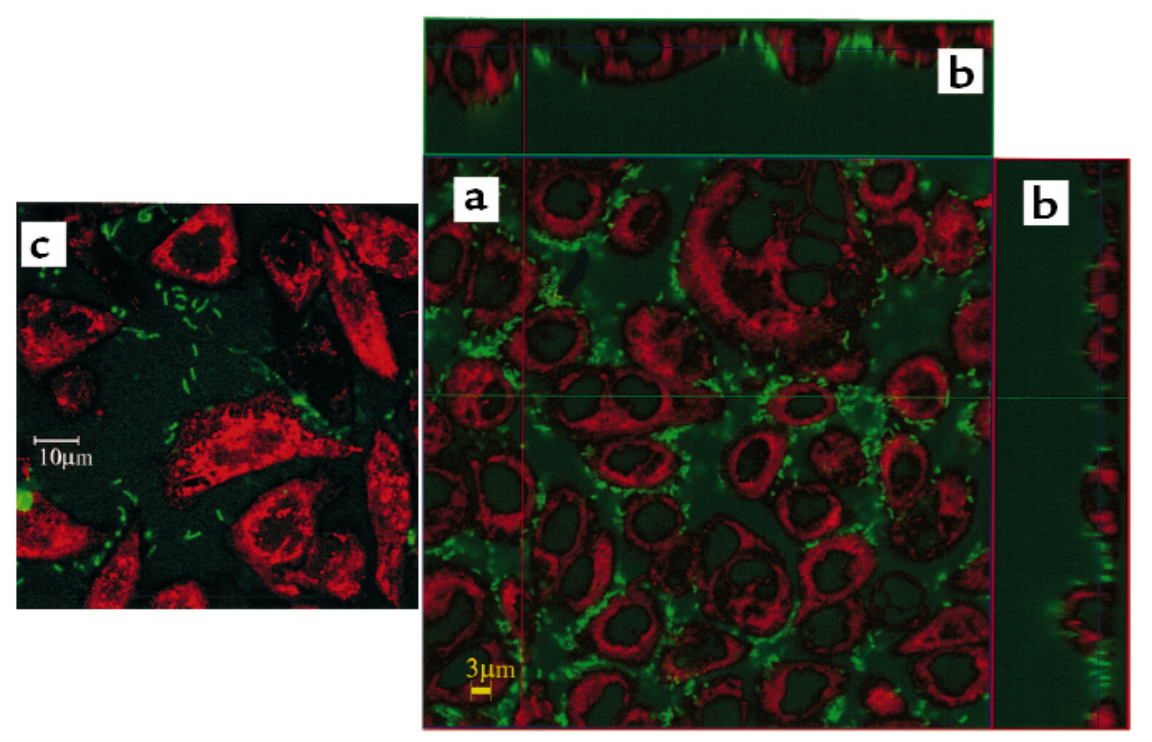

\section{Figure 1}

Localization of $H$. pylori in coculture with AGS cells. (a) AGS cells were stained with the dye $\mathrm{DiSC}_{3}(5)$ after 1-hour coculture with $H$. pylori. BCECF-free acid was used to illuminate the bacteria after addition of urea. Both dyes were monitored simultaneously using confocal microscopy. $\times 63$. (b) These images show a perpendicular cut through the same sample as panel $\mathbf{a}$ in the $X$ and in the $Y$ plane as shown by the corresponding lines of a. H. pylori are located primarily just above the regions of contact between the AGS cells. (c) A higher magnification view to illustrate that the peribacterial region of individual organisms shows the change in BCECF fluorescence. $\times 100$. The bars correspond to 3 or $10 \mu \mathrm{m}$ as defined by the confocal software.
Video microscopy perfusion experiments using BCECF-AM for determining effects on cell $p H$. $H$. pylori-AGS cells cocultured on cover slips for 1 hour (bacteria per cells $=200)$ were preincubated with BCECF-AM $(2 \mu \mathrm{M})$ for 30 minutes at $37^{\circ} \mathrm{C}$. The cover slip was placed in the microscope chamber and perfused with $5 \mathrm{mM}$ urea added to PBS (Hp buffer, as described earlier) containing $138 \mathrm{mM} \mathrm{NaCl}, 5 \mathrm{mM} \mathrm{KCl}, 1.2 \mathrm{mM} \mathrm{CaCl}_{2}, 0.5$ $\mathrm{mM} \mathrm{MgSO}_{4}, 10.0 \mathrm{mM}$ glucose, $1.0 \mathrm{mM}$ glutamine (1.0), and $1 \mathrm{mM} \mathrm{Na}$ phosphate adjusted to $\mathrm{pH} 5.5$; and the perfusate was collected. $\mathrm{HCl}$ was added as necessary to maintain the $\mathrm{pH}$ at 5.5 , as there was rapid elevation of the $\mathrm{pH}$ during perfusion. Then the coculture perfusate, collected at $\mathrm{pH} 5.5$ in the presence of $5 \mathrm{mM}$ urea, was perfused for 5 minutes over AGS cells at $37^{\circ} \mathrm{C}$ either before or after neutralization with $\mathrm{NaOH}$. The intracellular $\mathrm{pH}$ was monitored in ratio mode by alternating the excitation wavelength between 490 and 430 and measuring emitted fluorescence at $530 \mathrm{~nm}$. Intracellular $\mathrm{pH}$ changes were expressed as a change in the fluorescence ratio. In experiments not shown, $20 \mathrm{mM} \mathrm{NH}_{4} \mathrm{Cl}$ was added to the perfusion medium at $\mathrm{pH} 7.4$ and subsequently removed to show that $\mathrm{NH}_{3}$ entry into AGS cells elevated, and exit from AGS cells reduced, $\mathrm{pH}_{\mathrm{in}}$.

Measurement of $\left[\mathrm{Ca}^{2+}\right]_{\text {in }}$ of AGS cells. H. pylori and AGS cells in 1 hour coculture (bacteria per cells $=200$ ) were loaded with $2 \mu \mathrm{M}$ Fura 2 -AM for 30 minutes at $37^{\circ} \mathrm{C}$. The cover slip was washed with growth medium and placed in a heated chamber (Medical Systems Inc.). The experimental procedure followed exactly that described earlier here for measurement of intracellular pH. Fura-2 fluorescence was measured by alternating the excitation wavelengths at 340 and $380 \mathrm{~nm}$ with emission wavelength at $505 \mathrm{~nm}$. Image pairs were captured under the control of Image-1/FL software (Universal Imaging, West Chester, Pennsylvania, USA) and expressed as the ratio of fluorescence level in the chosen field (33). All data presented in the figures are representative of at least four experiments.

Materials. Chemicals were at least analytical grade. Biologic material was obtained as outlined above. BCECF, BCECF-AM, Fura2-AM, and SNARF-AM were purchased from Molecular Probes Inc.

\section{Results}

Localization of $H$. pylori on confluent AGS cells. AGS cells grown to confluence have regions of contact but do not form tight junctions. The staining of AGS cell mitochondria by $\operatorname{DiSC}_{3}(5)$ is shown as red in Figure 1a $(\times 63)$ and Figure $1 \mathrm{c}(\times 100)$, and the bacteria stained with BCECF, as green. These images are achieved immediately after the addition of urea. Figure 1c shows that individual bacteria are seen and that the peribacterial region shows $\mathrm{pH}$ elevation. The bacteria adhere to the AGS cells, forming a rosette around the cells. When viewed in the $z$ axis, the bacteria are clustered just above the contact regions between the cells (Figure 1b). Further, the bacteria adhering to the AGS cells were immobilized as compared to adherence to a Cell-Tak-coated cover slip (Collaborative Biomedical Products, Bedford, Massachusetts, USA). This specific location and immobilization in one plane are convenient for finding the organism in the confocal microscope and essential for the experiments defining regions of $\mathrm{pH}$ change. It was noted in electron micrographs $(\mathrm{H}$. Helander, unpublished observations) that pedestals were formed under the bacteria with distortion of the underlying structures consistent with the ability of $H$. pylori to carry out type IV secretion when cocultured with these cells (24). The size of the bacteria as determined by the computer in the confocal microscope is of the expected size, approximately $2.5 \mu \mathrm{m}$ (Figures 1 , a and c, and 2).

Localization of $p H$ elevation with urea addition. The outer membrane of this Gram-negative organism is permeable, and the inner membrane is impermeable, 
at $\mathrm{pH}$ greater than approximately 5.0 to the $\mathrm{pH}$-sensitive carboxylic acid dye, BCECF. Thus, this dye is able to monitor $\mathrm{pH}$ changes outside the bacterial inner membrane (periplasm and medium) when added at $\mathrm{pH}$ 5.0. BCECF has a $\mathrm{pK}_{\mathrm{a}}$ of 6.0 and can monitor $\mathrm{pH}$ between about 5.5 and 8.0, its fluorescence increasing with increasing $\mathrm{pH}$.

In wild-type bacteria, the addition of 1 or $5 \mathrm{mM}$ urea initially causes an increase in fluorescence at the periphery of the organisms, with the cytoplasm remaining dark (Figure 2a). At higher magnification, the fluorescence peripheral to the center of the organism is more obvious and the size measurement shows that this image, as in Figure 2a, comes from a single organism (Figure 2b). This restricted region of increased fluorescence $(\mathrm{pH})$ is the periplasm. In Figure 2, a and b, the medium adjacent to the organisms has not yet shown an increase of $\mathrm{pH}$. The addition of $0.01 \% \mathrm{C}_{12} \mathrm{E}_{8}$ before adding urea results in increased fluorescence in the bacterial cytoplasm because now the BCECF has access to the cell interior. Figure 2, d and e, shows a similar set of experiments in the ureI-negative mutant. There is no change of fluorescence near the ureI mutant with urea addition, showing that neither the surface nor intrabacterial urease of the ureI- mutants enable an initial rapid $\mathrm{pH}$ change (12). Detergent treatment results in an increase of $\mathrm{pH}$ only inside the organism with urea addition (Figure 2e). The arrow in Figure 2e points to a region of electronic magnification within the highlighted rectangle where the centrally greater fluorescence is evident compared with the lower peripheral fluorescence in contrast to Figure 2, a and b. The regulated or unregulated urea permeability of the inner membrane is bypassed by low concentrations of detergent in both wild-type and mutant organisms.

These data and the previous data for urease activation of intact bacteria and urea transport in Xenopus oocytes show that UreI controls urease activity of the organism by increasing urea permeability of the inner membrane at acidic $\mathrm{pH}$. This allows rapid buffering of the periplasm, as has been deduced from membrane potential measurements $(11,12)$.

\section{Effects of urea addition on medium $\mathrm{pH}$ in coculture}

Wild type. The addition of $5 \mathrm{mM}$ urea at a medium $\mathrm{pH}$ of 5.5 produced a rapid exponential rise of medium $\mathrm{pH}$ in the first 3-4 minutes as measured by the $\mathrm{pH}$ electrode (Figure 3a). Thereafter there was a slow increase of $\mathrm{pH}$ to about 7.2 over the next 16 minutes. The image sequence above the $\mathrm{pH}$ curve in Figure 3a, from the same experiment, shows the fluorescence increasing markedly first at the bacteria, evident in the first two or three images. In particular, in the second image, the square highlights a region of $\times 1.5$ magnification showing the increase of fluorescence first in the region of the bacteria. The increase in fluorescence then spreads rapidly into the medium, indicative of an increase in medium $\mathrm{pH}$. The fluorescence was close to maximum after about 4 minutes (fourth image), as for $\mathrm{pH}$ electrode measurements. A total of $1 \mu \mathrm{M}$ flurofamide 2 minutes before the experiment did not inhibit the changes of BCECF fluorescence (data not shown). However, 10 $\mu \mathrm{M}$ flurofamide inhibited the $\mathrm{pH}$ changes due to urea addition either in the wild-type organism or in the mutant with detergent addition (Figure 3e). Table 1 shows the time taken from urea addition to the start of $\mathrm{pH}$ increase in the peribacterial region compared with the medium in several experiments, confirming the visual impressions from the displayed images.
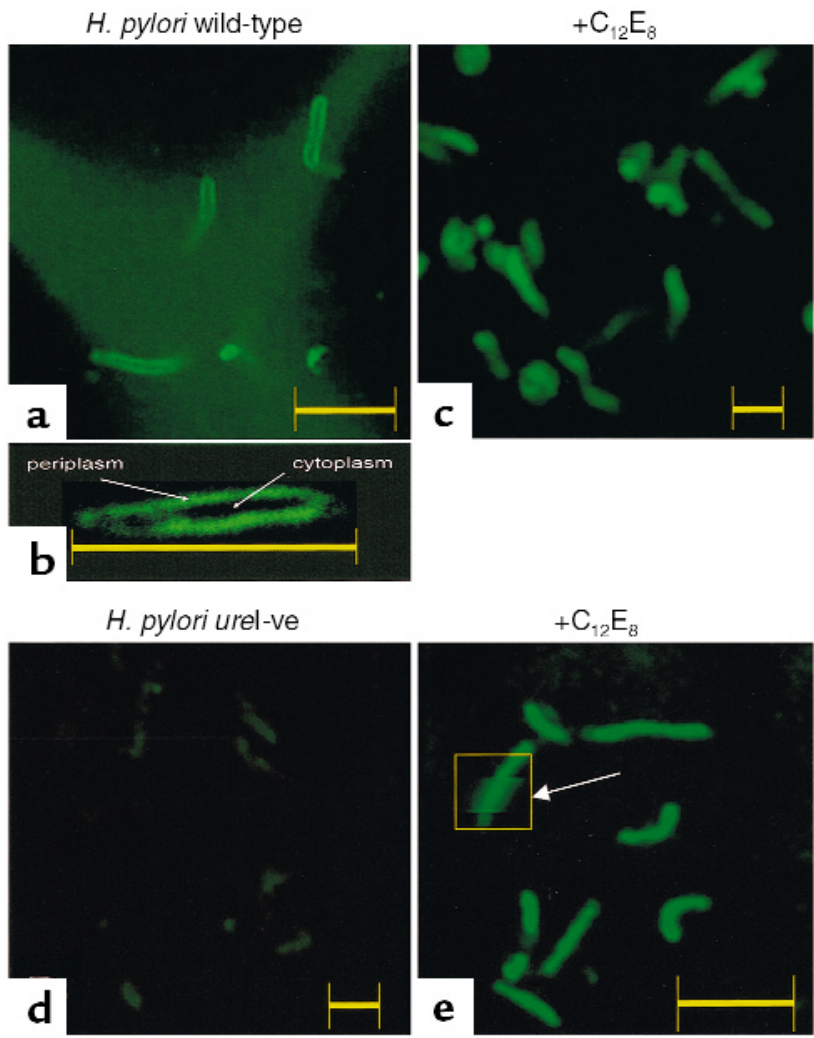

Figure 2

Localization of $\mathrm{pH}$ elevation with urea addition at $\mathrm{pH}_{\text {out }}$ 5.5. H. pylori cocultured with AGS cells were perfused with medium containing BCECF-free acid and then $5 \mathrm{mM}$ urea added as detailed in the text. Changes of fluorescence were then observed as a function of time using confocal microscopy at $\times 100$ optical magnification and $\times 3$ or $\times 10$ electronic magnification. (a) The addition of $5 \mathrm{mM}$ urea initially resulted in an increase of BCECF fluorescence clearly visible at the periphery of the wild-type organisms. (b) Higher magnification of a single wild-type organism emphasizing the peripheral increase of BCECF fluorescence obtained with urea addition. This restricted region of $\mathrm{pH}$ elevation is the periplasm. (c) Pretreatment with $0.01 \%$ $\mathrm{C}_{12} \mathrm{E}_{8}$ resulted in bacterial cytoplasmic alkalinization after the addition of urea to wild-type organisms. (d) Addition of $5 \mathrm{mM}$ urea resulted in little or no change of fluorescence $(\mathrm{pH})$ in the periplasm of the $H$. pylori urel-ve mutant with the addition of $5 \mathrm{mM}$ urea. (e) Pretreatment of the urel-ve mutants with $0.01 \% \mathrm{C}_{12} \mathrm{E}_{8}$ followed by urea addition increased cytoplasmic $\mathrm{pH}$ as monitored by the rise in $\mathrm{BCECF}$ fluorescence within the organism. The arrow points to a region where the image is electronically magnified to show the internal, compared with surface, fluorescence. Each bar corresponds to $3 \mu \mathrm{m}$ as defined by the confocal software. 
a
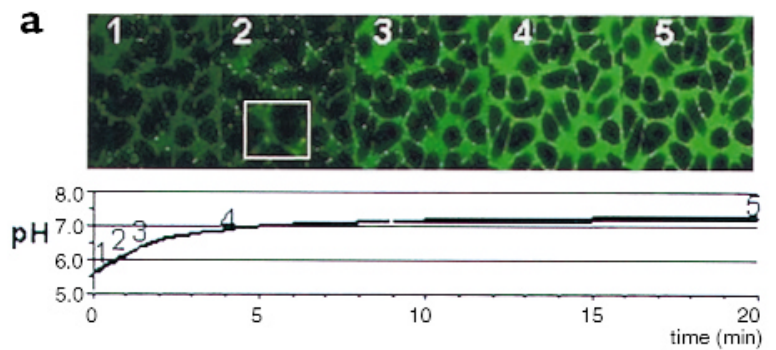

\section{5}

e (min)
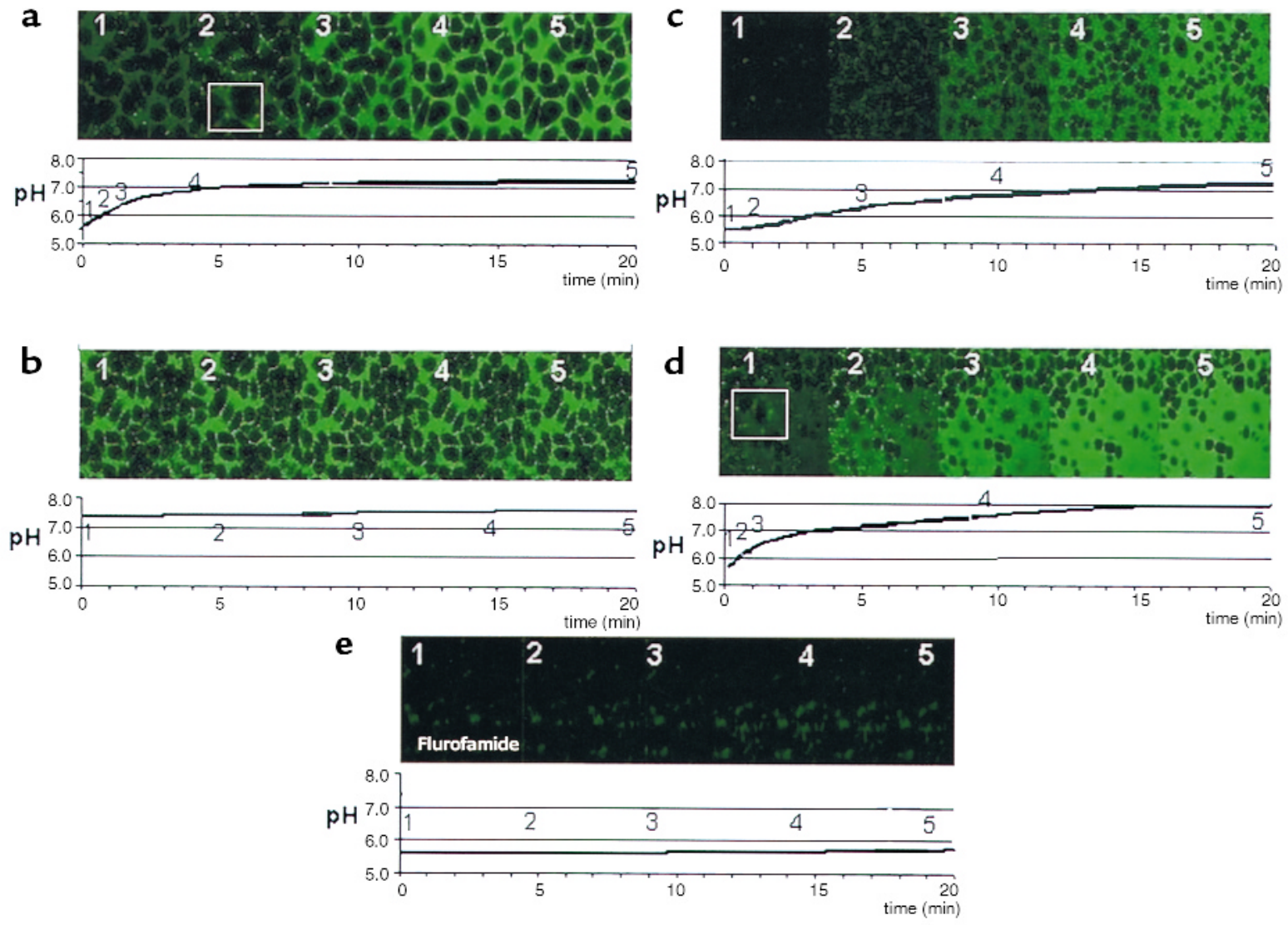

\section{Figure 3}

Bacterial and medium pH effects of urea addition to $H$. pylori-AGS coculture with either wild-type or urel mutant strains. (a and $\mathbf{b})$ The effect of urea addition on medium and bacterial $\mathrm{pH}$ in coculture with $\mathrm{H}$. pylori expressing Urel. H. pylori and AGS cells in coculture were perfused with medium containing BCECF-free acid at the indicated $\mathrm{pH}$ and then $5 \mathrm{mM}$ urea was added. A calibrated $\mathrm{pH}$ microelectrode was placed in the chamber to monitor medium $\mathrm{pH}$ and confocal microscopy was used to monitor the regions of change of $\mathrm{pH}$ after the addition of $5 \mathrm{mM}$ urea using wildtype or urel-deletion mutants as detailed in Methods. The numbering in the confocal images corresponds in time to the images above the $\mathrm{pH}$ tracings. (a) At a medium $\mathrm{pH}$ of 5.5, there was a rapid rise of medium $\mathrm{pH}$ after the addition of $5 \mathrm{mM}$ urea. Within 2 minutes, the $\mathrm{pH}$ had risen to 6.0 and reached a steady-state $\mathrm{pH}$ of about 7.0 within 5 minutes. In the image sequence above the $\mathrm{pH}$ curve from the same experiment, the fluorescence increased markedly first on or at the bacteria, evident in the first two or three images. The increase in fluorescence then spread into the medium as medium $\mathrm{pH}$ increased and is close to maximum at about 4 minutes (see Table 1). (b) In contrast, when urea is added at $5 \mathrm{mM}$ at a medium $\mathrm{pH}$ of 7.4, there was little change of medium $\mathrm{pH}$ or the $\mathrm{pH}$ around the organism. After 20 minutes, the $\mathrm{pH}$ had only increased by $0.2 \mathrm{U}$. (c and $\mathbf{d}$ ) The effect of $5 \mathrm{mM}$ urea addition on medium and bacterial $\mathrm{pH}$ in coculture with $\mathrm{H}$. pylori urel-negative mutants. (c) When urea was added at $\mathrm{pH} 5.5$ to the urel-ve strain, there was a slow rise of medium $\mathrm{pH}$, reaching about 6.5 after 5 minutes and then rising slowly to 7.2 at the end of the experiments. There was no obvious change of fluorescence with the addition of urea in the vicinity of the organisms, although they have considerable surface urease activity (11). (d) Urea addition in the presence of $0.01 \% \mathrm{C}_{12} \mathrm{E}_{8}$ to the urel-deletion mutant resulted in a rapid change in medium $\mathrm{pH}$, faster than that seen with the wild-type organisms, reaching $\mathrm{pH} 7.1$ within 5 minutes and continuing to increase to more than 8.0 , in contrast to the untreated wild-type organisms. In the fluorescence images, there was a similar increase in the fluorescence of the medium reflecting the $\mathrm{pH}$ changes monitored with the $\mathrm{pH}$ electrode. (e) When $5 \mathrm{mM}$ urea was added in the presence of $10 \mu \mathrm{M}$ flurofamide at $\mathrm{pH} 5.5$, no change in either bacterial or medium $\mathrm{pH}$ could be observed, showing the dependence of these changes on urease activity.

BCECF has greater fluorescence at $\mathrm{pH} 7.4$ than at $\mathrm{pH}$ 5.5. Therefore, in the experiments beginning with a medium $\mathrm{pH}$ at 7.4, the BCECF was already fluorescent. When $5 \mathrm{mM}$ urea was added at a medium $\mathrm{pH}$ of 7.4, there was little change of medium $\mathrm{pH}$ or organism $\mathrm{pH}$ (Figure $3 \mathrm{~b}$ ). After 20 minutes, medium $\mathrm{pH}$ had only increased by 0.2 units. This minimal increase is accounted for by the low intrabacterial urease activity due to absence of UreI induced urea permeability at this $\mathrm{pH}(11,12)$.

ureI-ve mutants. When urea was added at $\mathrm{pH} 5.5$ to $H$. pylori ureI-ve/AGS coculture, there was a slow increase of medium $\mathrm{pH}$ with time (Figure $3 \mathrm{c}$ ). The medium $\mathrm{pH}$ increased to about 6.2 after 5 minutes and to 7.2 after 20 minutes. In contrast to the observations with the wildtype strain of the bacteria, there was no change of fluorescence in the vicinity of the organisms after urea addition, despite having considerable surface urease activity as noted earlier (11). In data not shown, $1 \mu \mathrm{M}$ flurofamide added 2 minutes before urea addition, which selectively inhibits surface, but not intrabacterial urease, abolished the $\mathrm{pH}$ change seen with urea addition to these mutants. This shows that the $\mathrm{pH}$ change observed both with the $\mathrm{pH}$ electrode and with BCECF is due to mainly to external urease activity in the ureI deletion strain. 
Table 1

Time from urea addition to start of fluorescence change (seconds \pm SEM; $n=6$ )

\begin{tabular}{lccc}
\hline & H. pylori & Medium & AGS cells \\
BCECF alone & $7.66 \pm 0.97$ & $10.21 \pm 1.33$ & \\
BCECF + SNARF-AM & $7.65 \pm 1.77$ & $10.20 \pm 1.83$ & $17.16 \pm 1.6$
\end{tabular}

$P<0.01$ for all differences.

To confirm that slow fluorescence changes in the medium or the absence of localized changes of fluorescence at the surface of the organism was due to poor penetration of urea to the intrabacterial urease, a low concentration of the detergent $\mathrm{C}_{12} \mathrm{E}_{8}$ was added (Figure $3 \mathrm{~d}$ ). This $0.01 \%$ concentration of detergent permeabilizes the inner membrane of the organism with resultant full urease activity $(11,12)$, as urea penetration is no longer rate limiting. Detergent addition resulted in a rapid increase of medium $\mathrm{pH}$ to 7.1 after 3 minutes and to 8.0 after 20 minutes. The rate and magnitude of alkalinization were faster than that seen with the wildtype organisms in the absence of detergent (Figure 3a). In the images, there was consistently an increase first in the fluorescence of bacteria and then the medium as illustrated in the magnified panel in the first image of this sequence.

To exclude an effect of $\mathrm{C}_{12} \mathrm{E}_{8}$ in the coculture system, AGS cells were incubated with $0.01 \% \mathrm{C}_{12} \mathrm{E}_{8}$ without $H$. pylori and the fluorescence was followed after addition of $5 \mathrm{mM}$ urea. In another experiment, the medium fluorescence in the coculture was monitored after addition of $0.01 \% \mathrm{C}_{12} \mathrm{E}_{8}$ lacking urea. In both control experiments, no fluorescence change was observed.

Effect of $\mathrm{NH}_{3}$ generation on $A G S$ cell $p H_{\text {in }}$ and $\left[\mathrm{Ca}^{2+}\right]_{\text {in }}$. A question that can be answered directly using the coculture model is whether the ammonia produced by the organisms has privileged access to the cells to which they attach. As shown in Figure 4, the addition of urea results first in an increase of fluorescence in or around H. pylori as also illustrated in Figure 3 and Table 1. The blue rectangle is the region of interest chosen for monitoring bacterial fluorescence. This is followed by a change in medium $\mathrm{pH}$ spreading from the bacteria visible as increasing fluorescence where the region of interest is highlighted with a yellow rectangle. No change was observed in the AGS cells monitored simultaneously using intracellular SNARF (highlighted with a green rectangle) until the medium $\mathrm{pH}$ had changed. The graphs underneath illustrate a typical time course observed in terms of timing of $\mathrm{pH}$ changes as shown in Figures 2 and 3 and in this figure.

Table 1 also illustrates the time course of the initial changes of fluorescence in the peribacterial region, the medium and inside the AGS cells. Hence, cell $\mathrm{pH}$ does not increase until medium $\mathrm{pH}$ is elevated.

There is apparently no direct entry of $\mathrm{NH}_{3}$ into the AGS cells from the bacterial cytoplasm in this in vitro model, as cellular alkalinization would happen along with intrabacterial $\mathrm{NH}_{3}$ generation if there were direct transmission of $\mathrm{NH}_{3}$. Rather, the AGS cell alkalinization occurs after the medium $\mathrm{pH}$ is elevated by intrabacterial urease activity as illustrated in the graph, color images, and Table 1. This was investigated in more detail by perfusion with conditioned medium at $\mathrm{pH} 5.5$ and 7.4 as discussed later here.

Effects of addition of $\mathrm{NH}_{4} \mathrm{Cl}$ or cocultured supernatants on AGS cell $p H_{i n}$ and $\left[\mathrm{Ca}^{2+}\right]_{i n}$. BCECF-AM and Fura-2 AM were loaded into AGS cells and fluorescence measured with video microscopy for changes of $\mathrm{pH}$ and intracellular calcium. Because these are ratiometric fluorescent dye probes, the data are independent of microscope focus. When $20 \mathrm{mM} \mathrm{NH}_{4} \mathrm{Cl}$ was perfused across the AGS cells at $\mathrm{pH} 7.4$, there was a rise in $\mathrm{pH}_{\text {in }}$ that was maintained during the time of $\mathrm{NH}_{4} \mathrm{Cl}$ perfusion, as is characteristic of mammalian gastric cells due to $\mathrm{NH}_{3}$ entry (34). There is low permeability of the AGS cell to $\mathrm{NH}_{4}{ }^{+}$, so little equilibration of the $\mathrm{NH}_{3} / \mathrm{NH}_{4}{ }^{+}$couple occurs during the $\mathrm{NH}_{4} \mathrm{Cl}$ perfusion, maintaining a relatively high intracellular $\mathrm{pH}$. With removal of $\mathrm{NH}_{4} \mathrm{Cl}$ from the perfusate, there is rapid efflux of $\mathrm{NH}_{3}$, acidifying the cell.

Elevation of cell pH due to $\mathrm{NH}_{3}$ entry increased $\left[\mathrm{Ca}^{2+}\right]_{\text {in }}$ transiently, but there was no increase of steady-state intracellular calcium. This characteristic
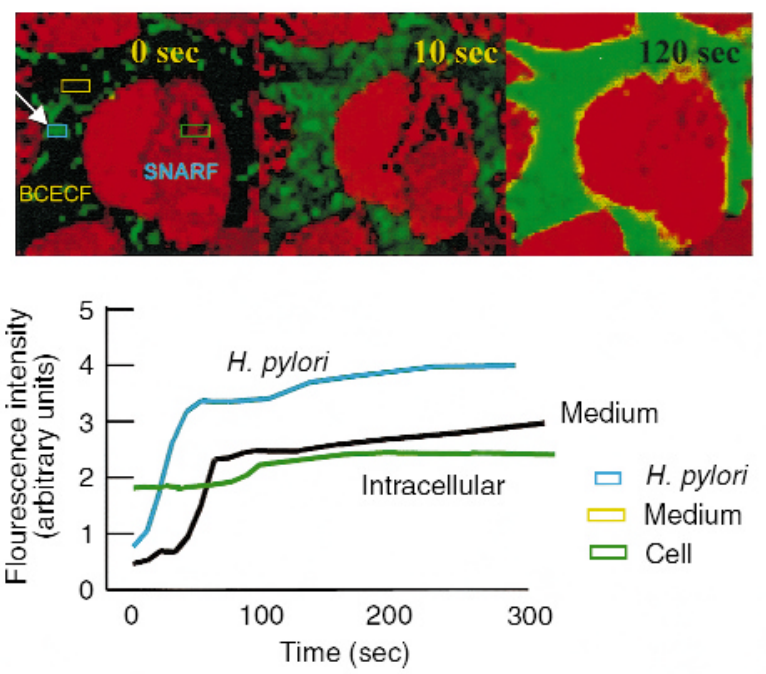

\section{Figure 4}

Time course of the effect of $\mathrm{NH}_{3}$ generation on peribacterial, medium, and AGS cell $\mathrm{pH}$. SNARF-AM was used to monitor the effect of $5 \mathrm{mM}$ urea addition to the $\mathrm{pH}_{\text {in }}$ of the AGS cells in bacterial coculture with $\mathrm{BCECF}$-acid present to monitor peribacterial and medium $\mathrm{pH}$ changes. Fluorescence changes were analyzed quantitatively on the bacteria, in the medium and in the cells in regions of interest defined by the confocal software (confocal images, rectangles) and displayed as a time course of fluorescence (graphs below). Three time points are illustrated in the confocal images corresponding to the time course shown in the time plot underneath. There was first a large change in periplasmic $\mathrm{pH}$ followed by an increase of medium $\mathrm{pH}$. No change was observed in the AGS cells until medium $\mathrm{pH}$ had risen. The earliest fluorescence change was seen over the bacteria, and then the increase spread into the medium and then into the AGS cells (see Table 1). 


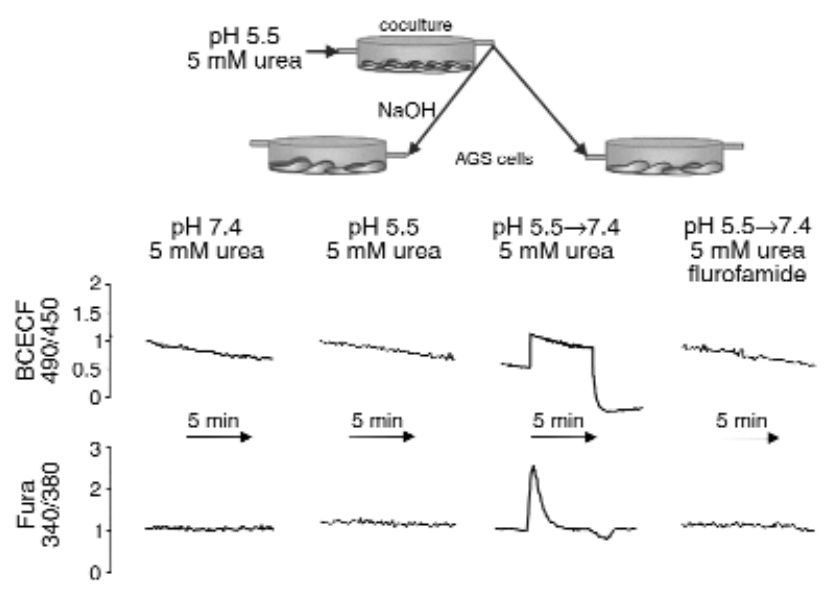

Figure 5

The effect of coculture perfusate on $\mathrm{pH}_{\text {in }}$ and $\left[\mathrm{Ca}^{2+}\right]_{\text {in }}$ of AGS cells. These experiments were designed to test the effects of ammonia generated by intrabacterial urease on the AGS cells cocultured with $H$. pylori either at acidic or neutral $\mathrm{pH}$. Bacteria and cells in coculture were perfused with $5 \mathrm{mM}$ urea at $\mathrm{pH} 7.4$ or 5.5 for 30 minutes, as illustrated in the diagram above the graphs, which shows the protocol for $\mathrm{pH} 5.5$ perfusion without or with $10 \mu \mathrm{M}$ flurofamide (also see Methods). The AGS cells were loaded in the microscopy chamber with BCECF-AM for $\mathrm{pH}_{\text {in }}$ measurement or Fura 2-AM for $\left[\mathrm{Ca}^{2+}\right]_{\text {in }}$ measurements. The coculture was reperfused with the conditioned perfusate generated at $\mathrm{pH} 7.4$ or 5.5 either before ( 2 curves on left) or after (2 curves on right) adjusting the $\mathrm{pH}$ to 7.4 with $\mathrm{NaOH}$, and changes of $\mathrm{pH}_{\text {in }}$ and $\left[\mathrm{Ca}^{2+}\right]_{\text {in }}$ were measured. The perfusion using conditioned medium at acidic $\mathrm{pH}$ resulted in no change in cell $\mathrm{pH}$ or calcium, whereas if the medium from the coculture was first neutralized to $\mathrm{pH} 7.4$ with $\mathrm{NaOH}$, a robust increase in intracellular $\mathrm{pH}$ or a transient increase in intracellular calcium was observed. The presence of flurofamide in the initial perfusion prevented any changes from being observed in the reperfusion at $\mathrm{pH} 7.4$ showing that the effect observed at $\mathrm{pH} 7.4$ reperfusion was due to the urease activity present during the $\mathrm{pH} 5.5$ initial perfusion.

transient is mainly due to release of calcium from intracellular stores. Acidification of the cell after removal of $\mathrm{NH}_{4} \mathrm{Cl}$ from the perfusate transiently lowered $\left[\mathrm{Ca}^{2+}\right]_{\text {in }}$ but to a lesser extent than alkalinization had increased $\left[\mathrm{Ca}^{2+}\right]_{\text {in. }}$. The $\left[\mathrm{Ca}^{2+}\right]_{\text {in }}$ increase seen in these experiments is directly dependent on cellular alkalinization because pretreatment with imidazole, a permeant intracellular buffer, abolished the $\mathrm{NH}_{4} \mathrm{Cl}$ induced $\mathrm{Ca}^{2+}$ signals (data not shown).

Perfusion of AGS cells with Hp/AGS coculture-derived medium at $\mathrm{pH} 5.5$ had no effect on intracellular $\mathrm{pH}$ or calcium. However, when the perfusate collected from the coculture chambers was first adjusted to $\mathrm{pH} 7.4$ before reperfusion, it induced a typical cellular alkalinization shift followed by acidification when washed out. This cellular $\mathrm{pH}$ shift was accompanied by $\mathrm{Ca}^{2+}$ release from intracellular stores (Figure 5). The latter effect is similar to that found with the addition of $\mathrm{NH}_{4} \mathrm{Cl}$ at neutral $\mathrm{pH}$. The supernatant-induced $\mathrm{pH}$ changes were absent if the initial perfusion of the coculture had been carried out in the presence of $10 \mu \mathrm{M}$ flurofamide, showing that it was ammonia/ammonium generation by urease that was responsible for these changes.

\section{Discussion}

Recent data have shown that intrabacterial, rather than surface, urease is the essential compartment of urease required for acid resistance of $H$. pylori $(7,10,12,35)$. This neutral $\mathrm{pH}$ optimum urease is limited in its activity, at a neutral medium $\mathrm{pH}$, by the slow penetration of urea into the organism, the major barrier being the inner membrane. The permeability of urea across unmodified lipid bilayers is $\sim 4 \times 10^{-6} \mathrm{~cm} / \mathrm{s}$ (36). This is insufficient to saturate intrabacterial urease at the prevalent gastric juice urea concentration, which lies between 1 and $3 \mathrm{mM}$ urea. The organism overcomes this limitation by expression of an $\mathrm{H}^{+}$-gated urea channel, UreI, which is encoded by one of the genes of the urease gene cluster. This protein has the function of accelerating urea entry at acidic $\mathrm{pH}$. These properties were identified by analysis of the acid activation of urease and by determining properties of UreI when expressed in Xenopus oocytes (7, 10-12). From a comparison of the urea concentration necessary for survival at $\mathrm{pH} 2.5$, it can be estimated that approximately 300 times more urea is required in ureI-ve compared with wild-type organisms to survive this acidity, i.e., UreI expression in $H$. pylori inner membranes increases urea permeability by a factor of 300 (D. Weeks, unpublished observations). This allows saturation of intrabacterial urease that has a $\mathrm{K}_{\mathrm{m} \text {,app }}$ of approximately $1 \mathrm{mM}$, close to the normal level of gastric juice urea.

The periplasm is the first site at which an elevation of $\mathrm{pH}$ is expected with the addition of urea to wild-type organisms in acidic media. In the absence of UreI, the periplasmic $\mathrm{pH}$ is not expected to change dramatically with urea addition, as there is little or no restoration of membrane potential in ureI- mutants with the addition of urea (11). In the wild-type organisms, but not in the mutants, the continuing efflux of $\mathrm{NH}_{3}$ from the cytoplasm to the periplasm and then across the outer membrane should secondarily alkalinize the medium, but the alkalinization will slow as UreI inactivates when periplasmic $\mathrm{pH}$ increases to greater than approximately 6.0. In the ureI-deletion mutants, it is predicted that no specific compartment should show a rapid change of $\mathrm{pH}$, but given the presence of finite urea permeability and/or the presence of surface urease, a slow alkalinization of the medium is expected. If the membrane barrier to urea is disrupted in the mutants (or in the wild-type organisms), as can be done by addition of low concentrations of detergent, the addition of urea should result in an even more rapid alkalinization than even in wild-type organisms at acidic $\mathrm{pH}$ and should be seen first in the cytoplasm and not slow down when the inactivation $\mathrm{pH}$ of UreI is reached. This is indeed what is found as shown in Figures 2 and 3.

These data extend our previous observations on the role of intrabacterial urease and UreI in which we monitored membrane potential or urease activity (11). 
From these data, we had deduced that the elevation of membrane potential at acidic $\mathrm{pH}$ with urea addition was due to a rise in periplasmic $\mathrm{pH}$. Here, this is directly demonstrated in the confocal images.

Accordingly, $H$. pylori can survive gastric acidity by buffering its periplasm, not the external environment, by stimulation of urease activity at acidic $\mathrm{pH}$ due to UreI enhancement of urea entry (12). Maintenance of the proton motive force across the inner membrane of the organism, as well as periplasmic $\mathrm{pH}$, is sufficient for viability and growth. This strategy adopted by these bacteria also minimizes the likelihood of excessive urease activity and toxic alkalinization in the absence of acid, further ensuring maintenance in a gastric environment of varying $\mathrm{pH}$.

Another issue addressed by this work was whether the ammonia generated inside the bacteria diffuses directly into cells to which they adhere. The data presented here show that $\mathrm{NH}_{3}$ does not diffuse directly from organism to infected cell. However, the quantity of $\mathrm{NH}_{3}$ and $\mathrm{NH}_{4}{ }^{+}$generated at $\mathrm{pH} \mathrm{5.5}$, a level at which urease activity plateaus, is sufficient, when brought back to neutrality, to alkalinize the AGS cells and induce a release of calcium from intracellular stores. Because inhibition of urease activity by flurofamide prevented these effects, they are due to the $\mathrm{NH}_{3}$ generated during incubation. These data, while showing that direct entry of $\mathrm{NH}_{3}$ into the gastric epithelial cells does not occur, also show that, when the $\mathrm{NH}_{4}{ }^{+}$-laden gastric juice is neutralized, as occurs during the digestive phase of acid secretion or upon entry into the duodenum or upon penetration to the base of the antral glands, sufficient $\mathrm{NH}_{3}$ is present to provoke cell alkalinization and initiation of a calcium-signaling cascade. This calcium signal may then provoke release of cytokines and thence gastritis, a universal pathological consequence of $H$. pylori infection of the human stomach (37).

\section{Acknowledgments}

This work was supported by United States Veterans Administration Senior Medical Investigator, and by NIH grants DK-46917, DK-53462, DK-41301, DK19567 , and DK-17294.

1. Marshall, B.J., and Warren, J.R. 1984. Unidentified curved bacilli in the stomach of patients with gastritis and peptic ulceration. Lancet. 1:1311-1315.

2. Andrutis, K.A., et al. 1995. Inability of an isogenic urease-negative mutant stain of Helicobacter mustelae to colonize the ferret stomach. Infect. Immun. 63:3722-3725.

3. Eaton, K.A., Morgan, D.R., Brooks, C.L., and Krakowka, S. 1991. Essential role of urease in the pathogenesis of gastritis induced by Helicobacter pylori in gnotobiotic piglets. Infect. Immun. 59:2470-2475.

4. Tsuda, M., Karita, M., Morshed, M.G., Okita, K., and Nakazawa, T. 1994 A urease-negative mutant of Helicobacter pylori constructed by allelic exchange mutagenesis lacks the ability to colonize the nude mouse stomach. Infect. Immun. 62:3586-3589.

5. Labigne, A., Cussac, V., and Courcoux, P. 1991. Shuttle cloning and nucleotide sequences of Helicobacter pylori genes responsible for urease activity. J. Bacteriol. 173:1920-1931.

6. Mobley, H.L.T., Island, M.D., and Hausinger, R.P. 1995. Molecular biology of microbial ureases. Microbiol. Rev. 59:451-480.

7. Scott, D.R., et al. 1998. The role of internal urease in acid resistance of Helicobacter pylori. Gastroenterol. 114:58-70.

8. Dunn, B.E., Campbell, G.P., Perez-Perez, G.I., and Blaser, M.J. 1990.
Purification and characterization of urease from Helicobacter pylori.J. Biol. Chem. 265:9464-9469.

9. Hawtin, P.R., Stacey, A.R., and Newell, D.G. 1990. Investigation of the structure and localization of the urease of Helicobacter pylori using monoclonal antibodies. J. Gen. Microbiol. 136:1995-2000.

10. Rektorschek, M., Weeks, D., Sachs, G., and Melchers, K. 1998. The influence of $\mathrm{pH}$ on metabolism and urease activity of Helicobacter pylori. Gastroenterol. 115:628-641.

11. Scott, D.R., et al. 2000. Expression of the Helicobacter pylori ureI gene is required for acidic $\mathrm{pH}$ activation of cytoplasmic urease. Infect. Immun. 68:470-477.

12. Weeks, D.L., Eskandari, S., Scott, D.R., and Sachs, G. 2000. A H ${ }^{+}$gated urea channel: the link between Helicobacter pylori urease and gastric colonization. Science. 287:482-485.

13. Skouloubris, S., Thiberge, J.-M., Labigne, A., and De Reuse, H. 1998. The Helicobacter pylori UreI protein is not involved in urease activity but is essential for bacterial survival in vivo. Infect. Immun. 66:4517-4521.

14. Eaton, K.A., and Krakowka, S. 1994. Effect of gastric pH on ureasedependent colonization of gnotobiotic piglets by Helicobacter pylori. Infect. Immun. 62:3604-3607.

15. Morgan, D.R., Freedman, F., Depew, C.E., and Kraft, W.G. 1987. Growth of Campylobacter in liquid media. J. Clin. Microbiol. 25:2123-2125.

16. Wiegmann, T.B., et al. 1993. Simultaneous imaging of intracellular $\left[\mathrm{Ca}^{2+}\right]$ and $\mathrm{pH}$ in single MDCK and glomerular epithelial cells. Am. J. Physiol. 265:C1184-C1190.

17. El-Omar, E.M., et al. 2000. Interleukin-1 polymorphisms associated with increased risk of gastric cancer. Nature. 404:398-402.

18. Kusugami, K., et al. 1997. Mucosal chemokine activity in Helicobacter pylori infection. J. Clin. Gastroenterol. 25(Suppl. 1):S203-S210.

19. Maekawa, T., et al. 1997. Helicobacter pylori induces proinflammatory cytokines and major histocompatibility complex class II antigen in mouse gastric epithelial cells. J. Lab. Clin. Med. 130:442-449.

20. Tomb, J.F., et al. 1997. The complete genome sequence of the gastric pathogen Helicobacter pylori. Nature. 388:539-547.

21. Covacci, A., Telford, J.L., Del Giudice, G., Parsonnet, J., and Rappuoli, R. 1999. Helicobacter pylori virulence and genetic geography. Science. 284:1328-1333.

22. Segal, E.D., Cha, J., Lo, J., Falkow, S., and Tompkins, L.S. 1999. Altered states: involvement of phosphorylated CagA in the induction of host cellular growth changes by Helicobacter pylori. Proc. Natl. Acad. Sci. USA. 96:14559-14564.

23. Stein, M., Rappuoli, R., and Covacci, A. 2000. Tyrosine phosphorylation of the Helicobacter pylori CagA antigen after cag-driven host cell translocation. Proc. Natl. Acad. Sci. USA. 97:1263-1268.

24. Odenbreit, S., et al. 2000. Translocation of Helicobacter pylori CagA into gastric epithelial cells by type IV secretion. Science. 287:1497-1500.

25. Dockray, G.J. 1999. Gastrin and gastric epithelial physiology. J. Physiol. 518:315-324.

26. Schubert, M.L., and Makhlouf, G.M. 1987. Neural regulation of gastrin and somatostatin secretion in rat gastric antral mucosa. Am. J. Physiol. 253:G721-G725.

27. Richter-Dahlfors, A., Heczko, U., Meloche, R.M., Finlay, B.B., and Buchan, A.M. 1998. Helicobacter pylori infected human antral primary cell cultures: effect on gastrin cell function. Am. J. Physiol. 275:G393-G401.

28. Calam, J., Gibbons, A., Healey, Z.V., Bliss, P., and Arebi, N. 1997. How does Helicobacter pylori cause mucosal damage? Its effect on acid and gastrin physiology. Gastroenterology. 113(Suppl.):S43-S49.

29. Segal, E.D., Falkow, S., and Tompkins, L.S. 1996. Helicobacter pylori attachment to gastric cells induces cytoskeletal rearrangements and tyrosine phosphorylation of host cell proteins. Proc. Natl. Acad. Sci. USA. 93:1259-1264.

30. Rektorschek, M., et al. 2000. Acid resistance of Helicobacter pylori depends on the UreI membrane protein and an inner membrane proton barrier. Mol. Cell. Biol. 36:141-152.

31. Ausubel, F.M., et al. 1994. Current protocols in molecular biology. John Wiley and Sons Inc. New York, New York, USA. 1.5.1-1.7.5.

32. Heuermann, D., and Haas, R. 1998. A stable shuttle vector system for efficient genetic complementation of Helicobacter pylori strains by transformation and conjugation. Mol. Gen. Genet. 257:519-528.

33. Zeng, N., Walsh, J.H., Kang, T., Wu, S.V., and Sachs, G. 1997. Peptide YY inhibition of rat gastric enterochromaffin-like cell function. Gastroenterology. 112:127-135.

34. Muallem, S., Burnham, C., Blissard, D., Berglindh, T., and Sachs, G. 1985. Electrolyte transport across the basal lateral membrane of the parietal cell. J. Biol. Chem. 260:6641-6653.

35. Krishnamurthy, P., et al. 1998. Helicobacter pylori containing only cytoplasmic urease is susceptible to acid. Infect. Immun. 66:5060-5066.

36. Orbach, E., and Finkelstein, A. 1980. The non-electrolyte permeability of planar lipid bilayer membranes. J. Gen. Physiol. 75:427-436.

37. Mobley, H.L., Hu, L.T., and Foxal, P.A. 1991. Helicobacter pylori urease: properties and role in pathogenesis. Scand. J. Gastroenterol. Suppl. 187:39-46. 